implements, as such flaking is not required in their manufacture. With fortuitous flaking the rain of blows is practically incessant, and truncated flakes are of necessity produced.

Many of the specimens shown exhibited marked sinuous edges, but the blows which caused them were all oblique and impinged at varying angles.

(2) Experiments were performed in natural pressure by means of an ordinary and a differential screw press (with a rubber $\mathrm{ram})$, giving a pressure ranging from 40 to 300 tons to the square inch.

It was found that through a thin layer of sand the pressure was incapable of fracturing the thinnest flint flakes.

On a hard surface, the pressure and resistance being equal, flakes were detached from flint nodules showing two bulbs, one at each end of the flake and opposite to each other.

In the case of a flake detached by percussion, only one buib occurs. Therefore this fact provides an excellen test for differentiating between man's work and flaking by natural pressure.

If the under surface on which the flint rests is not sufficiently resistant, a flake detached shows only one bulb, which is entirely different from that produced by percussion.

When a suitable flint is carefully placed upon another equally suitable, and pressure applied, a "hollow-scraper" can be produced showing much finer flaking than that resulting from percussion.

It is known that the finer flaking on Neolithic implements, such as arrow-heads and "pigmies," is always produced by pressure applied by man.

A large number of specimens was shown to illustrate each experiment described.

\section{THE MEDICAL WORK OF THE LOCAL GOVERNMENT BOARD.}

THE report of the medical officer of the Local Government Board for the year I9IO-II ${ }^{1}$ has been issued with commendable promptitude. Dr. Newsholme's report, which occupies the first seventy pages of the volume, gives a comprehensive review of the public health in rgro and of the work of the medical department of the Board, and epitomises some special subjects considered during the year, public vaccination, and the auxiliary scientific investigations carried out for the Board.

The review of the public health gives some of the more important facts as to the incidence of particular diseases, and a comparison is given graphically for the ten years 1901-10. It is gratifying to find that there has been a decline in the death-rate for all the following:-general death-rate, infant mortality, enteric fever, scarlet fever, diphtheria, puerperal diseases and accidents, and phthisis and tuberculous diseases. Measles alone has not markedly diminished. One of the most striking declines in the death-rate is that of enteric fever, which has diminished from about 16 per 100,000 in I9OI to about 4.5 in I910, a percentage decline of 70 , representing a saving of nearly I0,000 lives in I910 compared with I90I, and a financial saving estimated at $1,49^{2}, 800 \mathrm{l}$. Pulmonary tuberculosis (phthisis, consumption) was responsible for 38,639 deaths in 1909, still a heavy mortality; but had the same deathrate existed in this year as in $187 \mathrm{I}-80$ the deaths would have been 78,308 : this saving of life represents a financial saving of nearly six millions sterling. Preventive medicine may well be proud of such results as these!

The circumstances of the outbreak of plague in Suffolk are discussed, but these have already been dealt with in our pages.

Of the auxiliary scientific investigations, Dr. Gordon has once more studied the types of streptococci present in the fauces in scarlet fever. He has found that the scarlatinal streptococci are indistinguishable from streptococci present in other disease processes; this leaves the problem of the etiology of scarlet fever still unsolved. Infantile diarrhœea has been investigated by Dr. C. J. Lewis at Birmingham,

I Fortieth Annual Report of the Local Government Board, Igro-It Supplement containing the Report of the Medical Officer for Ig10-II.
Dr. S. M. Ross at Manchester, Dr. R. A. O'Brien at London, and Dr. T. Orr at Shrewsbury: Of diarrhœa cases, $49 \cdot 2$ per cent. yield non-lactose fermenting organisms from the fæces; of non-diarrhœea cases, only I9.I yield similar organisms, showing a much greater frequency of non-lactose fermenters in diarrhoea than in health. No one type of organism, however, has been found with sufficient frequency to justify the assumption that the disease is necessarily or usually attributable to one and the same organism.

Dr. Andrewes contributes a study of the bacteria present in the air of sewers and drains, a subject previously investigated by him for the Board in 1906-8. In the case of sewers, the dissociation of micro-organisms from the sewage is very small. In the case of drains, where there may be much more splashing than in sewers, organisms dissociated from the sewage may be far more numerous and may be carried by air currents in large numbers for considerable distances.

Dr. Inman has studied the secondary infections in pulmonary tuberculosis. He considers that in nearly every case of "open tuberculosis" of the lungs the tubercle bacillus is the predominant infecting agent.

R. T. Hewlett.

\section{THE HEDLEY GOLD FIELD, BRITISH \\ COLUMBIA.}

THE mining town of Hedley on the Similkameen River, in British Columbia, a little west of the roth meridian and about twenty miles north of the United States boundary, is the most important mining camp in that district, and is of interest owing to the unusual character of its ores. The town is situated near the mouth of the Twenty Mile Creek, a canyon from 2500 to 4000 feet deep and with walls sloping at angles of $40^{\circ}$. The first mining claims were discovered there in 1894 , and though many small mineral deposits have been found in the district, there are only two producing mines, the Nickel Plate and the Sunnyside Mines, of which the former is the most productive gold mine in Canada.

The country consists of Upper Palæozoic rocks, doubtfully identified as Carboniferous; they include a lower series of limestones, quartzites, and argillites, a middle series of limestones and quartzites-the Nickle Plate Formation and an upper series of tuffs and volcanic breccias-the Red Mountain Formation. The sedimentary series was invaded in early Mesozoic times by intrusions of gabbro and diorite. The ore deposits are unique in America, for they are contact metamorphic deposits containing arsenopyrite as the principal gold-bearing mineral. The ores are developed along the contacts between the gabbro and diorite with the sedjmentary deposits. The igneous rocks have metamorphosed the limestones, but have had a comparatively small effect on the quartzites, argillites, and tuffs. The mineralisation is greatest where the contact alteration is greatest, and though gold is found in all the sulphides the highest values occur in the arsenopyrite. The granodiorite has had comparatively little effect either as a source of metamorphism or of ores, and the gabbro has been far more active than the diorite. The gabbro forms the foot-wall or is closely associated with the ore bodies in the two producing mines and in some of the smaller ore deposits.

After the intrusion of the igneous rocks the field was faulted and fissured; but neither faults nor fissures are of much economic importance. The faults were later in date than the ore bodies, and the fissures are filled with barren veins of quartz and calcite, and contain no ore deposits of commercial value. The ores, in fact, do not occur in well defined lodes, but they grade off imperceptibly into barren country rock. As the ore deposits occur parallel to the bedding planes, it has been suggested that the gold was originally scattered through the sedimentary rock, and has been concentrated by the igneous activity; this suggestion was all the more natural, as the gold has been found widely distributed through the sedimentary rocks. It is found in them, however, only within the sphere of influence of the

1 "The Geology and Ore Deposits of Hedley Mining District, British Columbia." By C. Camsell. Canada Department of Mines Geological Survey Branch, Memoir No. 2. Pp. $218+x x$ plates +8 figs +4 maps. (Ottawa, ro10.) 